African Crop Science Journal by African Crop Science Society is licensed under a Creative Commons Attribution 3.0 Uganda License. Based on a work at www.ajol.info/ and www.bioline.org.br/cs DOI: http://dx.doi.org/10.4314/acsj.v24i1.12S

\title{
ECONOMICS OF HERBICIDE WEED MANAGEMENT IN WHEAT IN ETHIOPIA
}

\author{
H. SARETA, WOGAYEHU WORKU and BEDADA BEGNA \\ Ethiopian Institute of Agricultural Research, P. O. Box 2003, Addis Ababa, Ethiopia \\ Corresponding author: hussiensareta@yahoo.com
}

\begin{abstract}
Effective use of herbicides for the control of annual grass and broadleaf weeds in wheat (Triticum aestivum L.) was not a reality in Ethiopia, until in recent years. This study aimed at evaluating different post-emergence herbicides against annual grasses and broadleaf weeds in wheat for selection and incorporation into an integrated weed management (IWM) system. The study was conducted at Kulumsa Agricultural Research Centre main station, Bekoji and Lole farm fields. Treatments included herbicides, namely, Mesosulfron methyl+Idosulfuron methyl sodium (liquid) 1 lit ha ${ }^{-1}$ a.i. Pyroxsulam (liquid) $0.51 \mathrm{ha}^{-1}$ a.i. hand weeding twice (30-35 and 55-60 days after emergence (DAE)); and a weedy check. Among the annual grass weeds, Snowdenia polystachya, Avena fatua, Bromus pectinatus, Phalaris paradoxa and Setaria pumila; and most broad leaf weeds like Polygonum nepalense, Guizotia scabra, Galinsoga parviflora and Gallium spurium were controlled with herbicide efficacy ranging from 75 to $100 \%$. Mesosulfron methyl +Idosulfron methyl sodium, Pyroxulam and hand weeded twice plots outyielded the weedy check by 63,58 and $53 \%$, respectively. Maximum wheat grain yield $\left(5,184 \mathrm{~kg} \mathrm{ha}^{-1}\right)$, biomass $\left(12,808 \mathrm{~kg} \mathrm{ha}^{-1}\right)$, thousand kernel weight (48.55) and hectoliter weight (74.2) were obtained due to the application of Mesosulfron methyl+Idosulfuron methyl sodium. In addition, the herbicide had a yield advantage over Pyroxsulam, two hand weedings and the weedy check by 12, 21 and 63\%, respectively. Application of Mesosulfron methyl + Idosulfuron methyl sodium (US $\$ 1,596.31 \mathrm{ha}^{-1}$ ) had the highest net field benefit compared to Pyroxsulam (US\$1,379.21 ha ${ }^{-1}$ ), two hand weeding (US $\$ 1,126.7 \mathrm{ha}^{-1}$ ) and weedy check (US $\$ 574.1 \mathrm{ha}^{-1}$ ) by 13.6, 29 and 64\%, respectively. Moreover, the herbicide was also economically profitable to farmers, providing a marginal rate of return (MRR) of $1,737 \%$. Sensitivity analysis ( ${ }^{\mathrm{a}} \mathrm{MRR}$ ) also remained the most profitable even when the price of herbicide increased by $20 \%$. Hence, Mesosulfron methyl +Idosulfuron methyl sodium at a rate of 1 lit ha $^{-1}$ is thebest herbicide for the effective control of annual grasses and broad leaf weeds in wheat and can be used as one of the component in Integrated Weed Management Program (IWM) in wheat fields.
\end{abstract}

Key Words: Idosulfuron methyl sodium, Mesosulfron methyl, Triticum aestivum

\section{RÉSUMÉ}

l'utilisation efficace d'herbicides pour le contrôle d'herbe annuelle et de mauvaises herbes broadleaf dans le blé (Triticum aestivum L.) n'était pas une réalité en éthiopie, jusqu'à au cours des dernières années. cette étude visait du fait d'évaluer de différents herbicides de post-émersion contre les herbes annuelles et les mauvaises herbes broadleaf dans le blé pour la sélection et l'incorporation dans une administration de mauvaise herbe intégrée (IWM) le système. l'étude a été accomplie au centre de recherche agricole kulumsa la station principale, Bekoji et les champs de ferme Lole. les traitements ont inclus des herbicides, à savoir, le méthyle de mesosulfron le sodium de méthyle d'idosulfuron 1 (liquide) allumé ha ${ }^{-1}$ a.i. pyroxsulam 0.51 (liquides) ha ${ }^{-1}$ main d'a.i. désherbant deux fois (30-35 et 55-60 jours après l'émersion (dae)); et un chèque malingre. Parmi les mauvaises herbes d'herbe annuelles, Snowdenia polystachya, Avena fatua, Bromus pectinatus, Phalaris paradoxa et Setaria pumila; et les plus larges mauvaises herbes de feuille comme Polygonum nepalense, Guizotia scabra, Galinsoga parviflora et le Gallium spurium ont été contrôlées avec l'effet d'herbicide aux limites de 75 à $100 \%$. Le méthyle de Mesosulfron que le sodium de méthyle d'Idosulfron, Pyroxulam et la main désherbée complotent deux fois dehors - a produit 
le chèque malingre par 63,58 et $53 \%$, respectivement. La production de grain de blé maximum $\left(5,184 \mathrm{~kg} \mathrm{ha}^{-1}\right)$, la biomasse $\left(12,808 \mathrm{~kg} \mathrm{ha}^{-1}\right)$, un mille de poids cardinal (48.55) et de poids d'hectolitre (74.2) a été obtenue en raison de l'application de méthyle Mesosulfron le sodium de méthyle d'Idosulfuron, Pyroxulam et la main désherbée conspirent deux fois dehors - a produit le chèque malingre par 63,58 et $53 \%$, respectivement. La production de grain de blé maximum $\left(5,184 \mathrm{~kg} \mathrm{ha}^{-1}\right)$, la biomasse $\left(12,808 \mathrm{~kg} \mathrm{ha}^{-1}\right)$, un mille de poids cardinal (48.55) et de poids d'hectolitre (74.2) a été obtenue en raison de l'application de méthyle Mesosulfron le sodium de méthyle d'Idosulfuron. En plus, l'herbicide avait un avantage de production sur Pyroxsulam, deux main weedings et le chèque malingre par 12, 21 et $63 \%$, respectivement. L'application de méthyle Mesosulfron le sodium de méthyle d'Idosulfuron (US $\$ 1,596.31$ ha $^{-1}$ ) avait le plus haut avantage net de terrain comparé à Pyroxsulam (US\$1,379.21 $\mathrm{ha}^{-1}$ ), deux main désherbante (US\$1,126.7 ha $\mathrm{ha}^{-1}$ ) et chèque malingre (US\$574.1 ha ${ }^{-1}$ ) par 13.6, 29 et $64 \%$, respectivement. e plus, l'herbicide était aussi économiquement profitable aux fermiers, en fournissant un taux marginal de retour (MRR) de 1,737 \%. L'analyse de sensibilité (aMRR) est aussi restée le plus profitable même lorsque le prix d'herbicide a augmenté de $20 \%$. Dorénavant, le méthyle de Mesosulfron le sodium de méthyle d'Idosulfuron à un taux de 1 allumé ha 1 est l'herbicide thebest pour le contrôle efficace d'herbes annuelles et de larges mauvaises herbes de feuille dans le blé et peut être utilisé comme une de la composante dans le Programme d'Administration de Mauvaise herbe Intégré (IWM) dans les champs de blé.

Mots Clés: le sodium de méthyle d'Idosulfuron, le méthyle de Mesosulfron, Triticum aestivum

\section{INTRODUCTION}

Ethiopia is the largest producer of wheat (Triticum aestivum) in sub-Saharan Africa. The current total area suited to wheat production in the country is estimated at over 1.6 million ha, with an average grain yield of 2.1 tonnes per hectare (CSA, 2012). Durum and bread wheat are the two major wheat varieties produced in the country, whose proportion in 1991 were about 60 and $40 \%$, respectively (Eshetu and Zerihun, 2003). Durum and emmer wheat are indigenous to Ethiopia and have been cultivated since the prehistoric period in the highlands.

Weed interference is one of the most important, but less understood factors, contributing to lowering the yields of wheat (Hassan and Marwat, 2001). Weeds reduce yields of the crop, deteriorate the quality of farm produce, and trim down the market value of wheat. An estimated yield loss of about $10 \%$ in the less developed countries and $25 \%$ in the least developed countries is caused by weeds (Akobundu, 1987).

In Ethiopia, a yield loss of above 36.3\% was recorded in wheat in uncontrolled plots (Rezene, 2005). Similarly, in a study of Avena abyssinica, Lolium temulentum L., Snowdenia polystachya and Phalaris paradoxa L. with bread wheat, yield losses of 48-86\% were recorded by the maximum weed density of 320 weed seedlings per $\mathrm{m}^{2}$ (Taye et al., 1996).
In Durum wheat, Convolvulus arvensis and Cyperus spp. pose significant yield losses. Besides, considerable yield losses of up to $60 \%$ have been recorded in irrigated wheat, due to Sorghum arundnaceae, Cyperus esculentus, Cyperus rotundus, Portulaca oleraceae, Corchorus olitorius and Sorghum arundinaceae (Kassahun et al., 1998).

Bromus pectinatus and Snowdenia polystachya are weed species that recently became prominent in the affected cropping systems in Ethiopia due to a weed population shift, attributed primarily to continuous cereal cropping and frequent use of selective herbicides against previously common grass weeds, such as Avena fatua (Tanner and Giref, 1991; Amanuel et al., 1992; Rezene and Yohannes, 2003). This study was designed to evaluate different herbicides for the control of annual grasses and broadleaf weeds in wheat and to incorporate the best herbicide in an integrated weed management programme.

\section{MATERIALS AND METHODS}

The study was conducted at Kulumsa Agricultural Research Centre main station, Bekoji and Lole (Ego) farmers field during the main cropping season of 2011/12 and 2012/13. Kulumsa is situated in the main wheat belt of Ethiopia at an altitude of 2200 m.a.s.l, located in the north periphery of Asella town. It lies at $8^{\circ} 01210^{\prime \prime} \mathrm{N}$ 
and $39^{\circ} 09211$ "E and receives mean rainfall of 832 $\mathrm{mm}$. The mean minimum and maximum temperature is 10 and $23{ }^{\circ} \mathrm{C}$, respectively.

Bekoji is found at $7^{\circ} 32237^{\prime \prime} \mathrm{N}$ and $39^{\circ} 15221^{\prime \prime}$ E, with an altitude of 2780 m.a.s.l and receives average rainfall of $1066 \mathrm{~mm}$; and the mean minimum and maximum temperatures of 9.6 and $24{ }^{\circ} \mathrm{C}$, respectively. Dominant soils in these areas are Luvisol and Nitosol, respectively.

Treatments included post-emergence herbicides, namely, Pyroxsulam (liquid) $0.5 \mathrm{lit}$ ha $^{-1}$ a.i., and Mesosulfron methyl +Idosulfuron methyl sodium (liquid) 1 lit ha ${ }^{-1}$ a.i.; two hand weedings, and a weedy check as the control. Herbicides were applied at 30-35 days after emergence (DAE); and hand weeding was done 30-35 and 55-60 DAE. The required quantity of the herbicide was calculated and measured out into a manual knapsack sprayer, and filled with water to a volume of 200 lit for each herbicide treatment. All the necessary agronomic practices were applied equally for all treatments.

Dendea bread wheat variety was used for the trials at different locations, at a seeding rate of $150 \mathrm{~kg} \mathrm{ha}^{-1}$, by row planting; and $100 \mathrm{~kg} \mathrm{ha}^{-1} \mathrm{Di}$ Ammonium Phosphate (DAP) and $50 \mathrm{~kg} \mathrm{ha}^{-1}$ Urea fertilisers were applied at the time of sowing for all the treatments, in plots of $5 \mathrm{~m}$ by $4 \mathrm{~m}$. The study was laid out in randomised complete block design (RCBD), in three replications.

Parameters measured included plant height, number of tillers, spike length, weed count before, two and four weeks after herbicide application, general weed control visual assessment using a scoring scale of 1-5 scale; $1=$ Complete eradication; $2=$ effective destruction; $3=$ proper reduction in growth and population; $4=$ reduced growth and population; and $5=$ healthy wheat plots. After harvesting, dry weed biomass, crop biomass, grain yield, thousand kernel weight (TKW), and Hector liter weight (HLW) were measured by taking their weights and counting the seed by a seed counter machine.

All data were subjected to statistical analysis using Proc GLM procedure in SAS (SAS Institute Inc, 1994). Comparisons among treatments, with significant differences, were based on LSD test at $\mathrm{P}<0.05$. Linear correlation was used to determine the association between grain yield and yield components, using Minitab Software.
Economic data were collected to compare the economic advantage of each herbicide in different treatments. These included variable input costs and costs for the herbicides and labour during the execution of the experiment. Costs of herbicides were obtained from pesticide companies and local distributing agencies.

Based on the data obtained from both locations, economic analysis was computed using partial budget analyses, Marginal Rate of Return (MRR) and sensitivity analysis even when herbicide cost was increased by 20\% (CIMMIT, 1988). The following formulae were used to compute partial budget and marginal rate of return (MRR) analysis, respectively.

Net field benefits (NBs) $=$ Gross field benefits (GB) - Total Variable costs (TVC) and

$$
\mathrm{MRR}=\mathrm{DNI} / \mathrm{DIC}
$$

Where: $M R R=$ the marginal rate of return; $\mathrm{DNI}=$ difference in net income compared with control; and $\mathrm{DIC}=$ difference in input cost compared with control.

\section{RESULTS AND DISCUSSION}

Efficacy of herbicides. All the treatments except untreated weedy check, were effective in controlling the target annual grass weeds like Snowdenia polystachya, Avena fatua, Bromus pectinatus, Phalaris paradoxa, Setaria pumila; and broad leaf weeds likeGizotia scabra, Galinsoga parviflora, Gallium spurium and Polygonum nepalense, at an efficacy rate of 75$100 \%$. Effectiveness of control of S. polystachya by Mesosulfron methyl +Idosulfron methyl sodium, Pyroxulam and two hand weeding was 100,75 and $100 \%$, respectively (Table 1). For that of A. fatua, Mesosulfron methyl +Idosulfron methyl sodium, Pyroxulam and two hand weedings controlled the weeds at efficacy rate of 87,88 and $100 \%$, respectively. Phalaris paradoxa was controlled by Mesosulfron methyl +Idosulfron methyl sodium, Pyroxulam and two hand weeding at $100 \%$ efficacy. Whereas, Bromus pectinatus was controlled at 85,100 and $100 \%$ efficacy, respectively (Table 1). Rezene et al. 
TABLE 1. Efficacy rate in percentof Mesosulfron methyl +ldosulfron methyl sodium as compared to Pyroxulam on major grass and broad leaf weeds two weeks after application at two locations in Arsi Zone, Ethiopia

\begin{tabular}{|c|c|c|c|c|c|c|c|c|c|c|c|c|c|}
\hline \multirow[t]{2}{*}{ Locations } & \multirow[t]{2}{*}{$\begin{array}{l}\text { Scientific name of weed } \\
\text { species }\end{array}$} & \multicolumn{3}{|c|}{$\begin{array}{l}\text { Mesosulfron methyl +Idosulfron } \\
\text { methyl sodium }\end{array}$} & \multicolumn{3}{|c|}{ Pyroxulam } & \multicolumn{3}{|c|}{ Twice hand weeding } & \multicolumn{3}{|c|}{ Untreated weedy check } \\
\hline & & $\begin{array}{c}\text { Weed } \\
\text { count } \\
\text { before } \\
\text { application }\end{array}$ & $\begin{array}{l}\text { Weed } \\
\text { count } \\
\text { after } \\
\text { application }\end{array}$ & $\begin{array}{l}\text { Efficacy } \\
(\%)\end{array}$ & $\begin{array}{l}\text { Weed } \\
\text { count } \\
\text { before } \\
\text { application } \\
\text { hand }\end{array}$ & $\begin{array}{c}\text { Weed } \\
\text { count } \\
\text { after } \\
\text { application } \\
\text { hand }\end{array}$ & $\begin{array}{c}\text { Efficacy } \\
(\%)\end{array}$ & $\begin{array}{l}\text { Weed } \\
\text { count } \\
\text { before } 1^{\text {st }} \\
\text { hand } \\
\text { weeding }\end{array}$ & $\begin{array}{l}\text { Weed } \\
\text { count } \\
\text { after } 2^{\text {nd }} \\
\text { hand } \\
\text { weeding }\end{array}$ & $\begin{array}{l}\text { Efficacy } \\
(\%)\end{array}$ & $\begin{array}{l}\text { Weed } \\
\text { count } 1^{\text {st }}\end{array}$ & $\begin{array}{l}\text { Weed } \\
\text { count } 2^{\text {nd }}\end{array}$ & $\begin{array}{l}\text { Efficacy } \\
(\%)\end{array}$ \\
\hline \multirow[t]{8}{*}{ Bekoji } & Snowdenia polystachya & 80 & 0 & 100 & 40 & 10 & 75 & 120 & 0 & 100 & 160 & 160 & 0 \\
\hline & Avena fatua & 68 & 9 & 87 & 56 & 6 & 89 & 42 & 0 & 100 & 0 & 0 & 0 \\
\hline & Bromus pectinatus & 3400 & 510 & 85 & 2180 & 0 & 100 & 1740 & 0 & 100 & 4200 & 4300 & -2.3 \\
\hline & Phalaris paradoxa & 25 & 0 & 100 & 260 & 0 & 100 & 100 & 0 & 100 & 300 & 340 & -11.7 \\
\hline & Gallium spurium & 58 & 0 & 100 & 43 & 5 & 88 & 5 & 0 & 100 & 3 & 4 & -25 \\
\hline & Polygonum nepalense & 117 & 0 & 100 & 55 & 0 & 100 & 50 & 4 & 92 & 45 & 47 & -4.2 \\
\hline & Gizotia scabra & 17 & 0 & 100 & 23 & 0 & 100 & 15 & 0 & 100 & 18 & 18 & 0 \\
\hline & Galinsoga parviflora & 0 & 0 & - & 0 & 0 & - & 68 & 3 & 95 & 56 & 56 & 0 \\
\hline \multirow[t]{8}{*}{ Lole } & Snowdenia polystachya & 1260 & 0 & 100 & 860 & 207 & 76 & 1140 & 0 & 100 & 1420 & 1460 & -2.7 \\
\hline & Avena fatua & 48 & 6 & 87.5 & 32 & 4 & 87.5 & 72 & 0 & 100 & 0 & 0 & 0 \\
\hline & Bromus pectinatus & 1720 & 256 & 85 & 1820 & 0 & 100 & 1220 & 0 & 100 & 2080 & 2140 & -2.8 \\
\hline & Phalaris paradoxa & 17 & 0 & 100 & 21 & 0 & 100 & 30 & 0 & 100 & 0 & 0 & 0 \\
\hline & Gallium spurium & 94 & 5 & 95 & 102 & 14 & 86 & 19 & 2 & 89 & 5 & 6 & -16.6 \\
\hline & Polygonum nepalense & 55 & 0 & 100 & 30 & 0 & 100 & 62 & 3 & 95 & 50 & 54 & -7.4 \\
\hline & Gizotia scabra & 5 & 1 & 80 & 9 & 0 & 100 & 11 & 0 & 100 & 15 & 15 & 0 \\
\hline & Galinsoga parviflora & 16 & 1 & 94 & 28 & 0 & 100 & 23 & 0 & 100 & 68 & 68 & 0 \\
\hline
\end{tabular}

Efficacy measured on quadrats of $1 \mathrm{~m}$ by $1 \mathrm{~m}$ 
(2007) reported that Propoxycarbozone-sodium (Attribut 70WG) was effective against Bromus pectinatus and gave satisfactory suppression of Snowdenia polystachya across locations of the experimental sites. On the other hand, Shambel et al. (2000) reported that the herbicides sulfosulforol and ethiozin, exhibited significant potential to control problematic grass weeds, including Brome grass in the wheat growing areas of Ethiopia. Similarly, both herbicides and two hand weedings controlled Gallium spurium, Gizotia scabra, Galinsoga parviflora and Polygonum nepalense at 80-100\% efficacy level (Table 1). The negative values in the efficacy column of the untreated weedy check is resulted from the increasing late emergence of the weeds after the second weed count.

Mesosulfron methyl +Idosulfuron methyl sodium is best recommended in areas where Snowdenia polystachya, Avena fatua, Phalaris paradoxa and Setaria pumila; and broad leaf weeds like Galinsoga parviflora, Gallium spurium, Gizotia scabra and Polygonum nepalense are problematic. For areas where Bromus pectinatus, Phalaris paradoxa, Setaria pumila, Lolium temulentum andbroad leaf weeds like Polygonum nepalense, Galinsoga parviflora, Gizotia scabra are dominant weed problems, it is better to use Pyroxsulam.

Yield and yield components. Grain yield of wheat showed significant $(\mathrm{P}<0.05)$ differences due to Mesosulfron methyl +Idosulfuron methyl sodium, Pyroxsulam and two hand weeding (Table 2 ). The highest grain yield was recorded in Mesosulfron methyl +Idosulfuron methyl sodium; followed by Pyroxsulam and two hand weedings. The lowest grain yield was recorded in weedy check treatment.

The combined analysis over locations was not significant for plant height, spike length, TKW and HLW, but significant for weed dry weight, crop biomass and grain yield compared to the weedy check (Table 2). Yield wise, both Mesosulfron methyl +Idosulfron methyl sodium, Pyroxulam and the two hand weedings outperformed the weedy check by 63, 58 and $53 \%$, respectively. Mesosulfron methyl +Idosulfron methyl sodium had a yield advantage

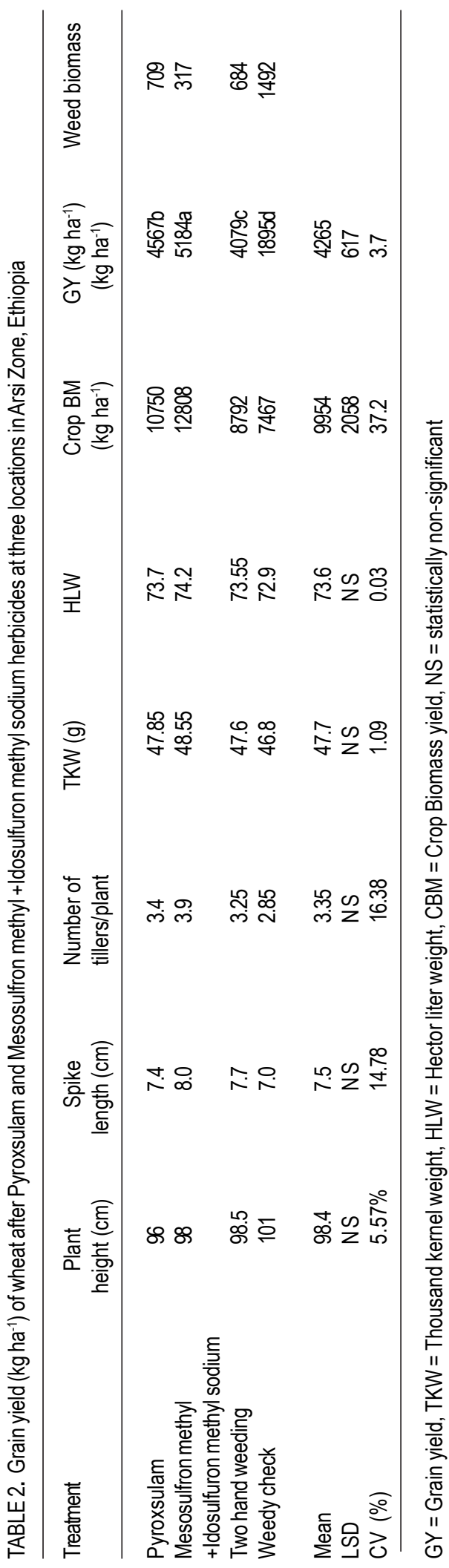


over Pyroxulam, the two hand weedings and the weedy check (Table 2).

Dry weed mass showed significant difference $(\mathrm{P}<0.05)$ due to Mesosulfron methyl +Idosulfuron methyl sodium, Pyroxsulam and the two hand weedings. The lowest dry weed mass was recorded in Mesosulfron methyl +Idosulfuron methyl sodium treated plot; followed by two hand weedings and Pyroxsulam herbicide. The highest dry weed mass was recorded in untreated weedy checks (Table 2).

Economic analysis. Yield and economic data were collected to compare the economic advantage of each herbicide in different treatments. Accordingly, cost of Pyroxsulam was US\$125 litre $^{-1}$ and the cost of Mesosulfron methyl
+Idosulfuron methyl sodium was US\$50 litre $^{-1}$ in 2012/13.

Labour costs for two hand weedings were determined by man-days and it was US\$ 156.25 $\mathrm{ha}^{-1}$. Harvesting and threshing was done manually at 20 and 30 man days per hectare, respectively, with one daily labourer cost of US $\$ 1,875$, and accordingly the cost for daily labourer for harvesting and threshing of wheat for Pyroxsulam, Mesosulfron methyl +Idosulfuron methyl sodium, two hand weeding and weedy check treatments was US $\$ 93.75,93.75$, 93.75 and $65.5 \mathrm{ha}^{-1}$, respectively. The average grain price of wheat was US $\$ 37.5$ per $100 \mathrm{~kg}$ in 2012/13 season. Labour cost for three times plowing was uniform for each treatment and cost US\$140.5 ha ${ }^{-1}$. Average daily labourer cost and

TABLE 3. Partial budget analysis for weed control with herbicides and two times hand weeding at three locations in Arsi Zonein Ethiopia

\begin{tabular}{|c|c|c|c|c|}
\hline \multirow[t]{2}{*}{ List of different costs } & \multicolumn{4}{|c|}{ Treatments } \\
\hline & Pyroxsulam & $\begin{array}{c}\text { Mesosulfron } \\
\text { methyl + Idosulfuron } \\
\text { methyl sodium }\end{array}$ & Two hand weeding & Weedy check \\
\hline Adjusted mean yield $\left(\mathrm{kg} \mathrm{ha}^{-1}\right)$ & 4110.3 & 4665.6 & 3671.1 & 1705.5 \\
\hline Gross field benefit (US\$) & 1541.4 & 1746 & 1376.7 & 639.6 \\
\hline Cost of herbicide (US\$) & 62.5 & 50 & - & - \\
\hline $\begin{array}{l}\text { Herbicide application cost and } \\
\text { rent for knapsack sprayer (US\$) }\end{array}$ & 5.94 & 5.94 & - & - \\
\hline Labor cost (US\$) & - & - & 156.25 & - \\
\hline Harvesting cost (US\$) & 37.5 & 37.5 & 37.5 & 28 \\
\hline Threshing cost (US\$) & 56.25 & 56.25 & 56.25 & 37.5 \\
\hline Total variable cost (US\$) & 162.19 & 149.69 & 250 & 65.5 \\
\hline Net field benefit (US\$) & 1379.21 & 1596.31 & 1126.7 & 574.1 \\
\hline
\end{tabular}

TABLE 4. Marginal rate of return analysis for weed control with herbicides and two times hand weeding at three locations in Arsi Zonein Ethiopia

\begin{tabular}{lrrrrr}
\hline Treatments & $\begin{array}{l}\text { Rate } \\
\left(\mathrm{I} \mathrm{ha}^{-1}\right)\end{array}$ & $\begin{array}{c}\text { Net field } \\
\text { benefit (US\$) }\end{array}$ & $\begin{array}{r}\text { Total variable } \\
\text { costs (US\$) }\end{array}$ & MRR & MRR a \\
\hline Weedy check & - & 574.1 & 65.5 & & \\
Pyroxsulam & 0.5 & 1379.21 & 162.19 & 733 & 1737 \\
Mesosulfron methyl + Idosulfuron methyl sodium & 1.0 & 1596.31 & 149.69 & 1464 \\
Two hand weeding & - & 1126.7 & 250 & $\mathrm{D}$ \\
\hline
\end{tabular}

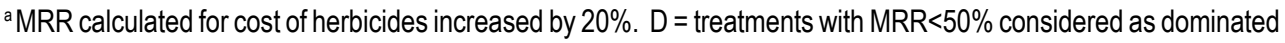


rent for knapsack sprayer for herbicide application was US \$5.94 ha ${ }^{-1}$. The cost for land preparation and inputs (seed and fertilisers) were uniform for all treatments. To minimise unnecessary exaggerations of grain yield, productivity of the location mean grain yield obtained was adjusted by $10 \%$.

Partial budget analysis indicated that application of Mesosulfron methyl + Idosulfuron methyl sodium had the highest net field benefits (Table 3). Similarly, the marginal rate of return (MRR) analysis revealed that Mesosulfron methyl + Idosulfuron methyl sodium was more profitable for farmers, and resulted in a MRR of $1737 \%$ (Table 4). In the sensitivity analysis ( $\left.{ }^{\mathrm{a}} \mathrm{MRR}\right)$, Mesosulfron methyl + Idosulfuron methyl sodium remained the most profitable weed treatment, even when the cost of herbicide was increased by $20 \%$.

\section{ACKNOWLEDGEMENT}

The Eastern Africa Agricultural Productivity Project (EAAPP) and the Ethiopian Institute of Agricultural Research (EIAR) are gratefully acknowledged for financial support. Authors thank the Association for Strengthening Agricultural Research in Eastern and Central Africa (ASARECA) for facilitating the publication of this paper.

\section{REFERENCES}

Akobundu, I.O. 1987. Weed Science in the tropics, Principles and practices. John Wiley and Sons, Ltd. New York, USA.

Amanuel Gorfu, Tanner, D.G. and Assefa Taa. 1992. On-farm evaluation of pre-and postemergence grass herbicides on bread wheat in Arsi Region of Ethiopia. pp. 330-337. In: Tanner, D.G. and Mwangi, W. (Eds). Proceedings of the Seventh Regional Wheat Workshop for Eastern, Central and South Africa, Addis Ababa, Ethiopia: CIMMYT.

CIMMYT. 1988. From agronomic data to farmer recommendations: An Economics Workbook. Mexico, D.F.: CIMMYT, ISBN 968-127-19-4 pp. 8-28.

CSA (Central Statistical Authority). 2012. Agricultural Sample Survey 2011/2012, Volume
I: Report on area and production of crops (Meher season). Statistical Bulletin No. 446. Addis Ababa, Ethiopia.

Eshetu Bekele and Zerihun Kassaye. 2003. Integrated management of Septoria blotches of wheat: Effect of sowing date, variety and fungicide. Pest Management Journal of Ethiopia 7:11-18.

Hassan, G. and Marrwat, K.B. 2001. Integrated weed management in Agricultural crops. Proceedings of the National Workshop on Technologies for Sustainable AgricUlture. September 24-26, 2001 NIAB, Faisalabad, Pakistan. pp. 27-34.

Kassahun Zewdie and Tanner, D.G. 1998. Pre- and post- emergence herbicides for irrigated wheat in Ethiopia. pp. 309-315. The $10^{\text {th }}$ Regional Wheat Workshop for Eastern, Central and Southern Africa, September 14-18, 1998, University of Stelenbosch, South Africa. ISBN 92-9146-058-3.

Rezene Fessehaie and Yohannes, L. 2003. Control of Snowdenia polystachya in large scale wheat production: Herbicide Resistance in context. pp. 79-88. Proceedings of the Agronomy Workshop, 20-21 March 2000, Melekassa, Ethiopia. Bale Agricultural Development Enterprise (BADE), Addis Ababa, Ethiopia.

Rezene Fessehaie. 2005. Weed science research and extension in Ethiopia: Challenges and responses. Key note address. Ethiopian Weed Science Society $7^{\text {th }}$ Annual Conference. 24 -25 November 2005, EARO,Addis Ababa, Ethiopia.

Rezene Fessehaie, Natenael Wassie and Kedija Demsiss. 2007. Effect of propoxycarbozonesodium and mesosulfuron-methyl for annual grass weed control in wheat. Ethiopian Journal of Weed Management 1:53-61.

SAS Institute Inc. 1994. SAS/STAT- Software: Changes and Enhancements through Release 9.0.SAS Institute Inc., Cory, NC., USA.

Shambel, M., Kefyalew, G. and Tanner, D.G. 2000. Evaluation of herbicides for the control of brome grass in wheat in Southeastern Ethiopia. In: CIMMYT. The Eleventh Regional Wheat Workshop for Eastern, Central and South Africa, Addis Ababa, Ethiopia: CIMMYT. 
Tanner, D.G. and Giref Sahle. 1991. Weed control Taye, T., Tanner, D.G. and Mengistu, H. 1996. research conducted in Ethiopia. pp. 235-276. In: Hailu Gebremariam, Tanner, D.G. and Mengistu Hulluka. (Eds.). Wheat Research Grass weeds competition with bread wheat in Ethiopia: I. Effect on selected crop and weed inEthiopia: A Historic Perspective. Addis vegetative parameters and yield components. Ababa: IAR/ CIMMYT. African Crop Science Journal 4: 399-409. 